\title{
The Mediating Role of Organizational Citizenship Behavior on the Effect of Passion and Empowerment on Job Performance
}

\author{
Prima Rizka Amalia*, Sri Handari Wahyuningsih, and Arni Surwanti
}

\begin{abstract}
:
Research aims: This research aims to analyze the mediating role of organizational citizenship behavior (OCB) on the effect of passion and empowerment on teachers' job performance.

Design/Methodology/Approach: Respondents in this research were Muhammadiyah elementary school teachers in Ngampilan and Wirobrajan Districts. This research used nonprobability purposive judgment sampling with the number of respondents as many as 51 teachers. Statistical tests and data processing were then carried out utilizing the Partial least Square (SmartPLS) 3.0. Research findings: The research found that passion had a positive and significant effect on organizational citizenship behavior. This research also revealed that organizational citizenship behavior and empowerment positively and significantly affected job performance, while passion was significant toward job performance with partial mediation of organizational citizenship behavior. Theoretical Contribution/Originality: OCB serves as a mediating variable in this analysis, while in previous studies, these variables were not mediated by OCB. Practitioners/Policy Implications: As a result, the principal must enable teachers to be flexible in their teaching and learning activities. Teachers must also be active in voluntary activities outside of teaching and learning that can enhance their abilities and skills to improve their performance.

Research Limitations/Implications: The study was only performed at Muhammadiyah elementary schools in Ngampilan and Wirobrajan Districts. Therefore, the collected data had a low degree of normality.

Keywords: Passion; Empowerment; OCB; Job Performance
\end{abstract}

AFFILIATION:

Master of Management, Universitas Muhammadiyah Yogyakarta, Special Region of Yogyakarta, Indonesia

*CORRESPONDENCE:

primarizkaa@gmail.com

THIS ARTICLE IS AVAILABLE IN:

http://journal.umy.ac.id/index.php/mb

DOI: $10.18196 / \mathrm{mb} . v 12 \mathrm{i} 2.11035$

\section{CITATION:}

Amalia, P.R., Wahyuningsih, S.H., \& Surwanti, A. (2021). The Mediating Role of Organizational Citizenship Behavior on the Effect of Passion and Empowerment on Job Performance. Jurnal Manajemen Bisnis, 12(2), 127-141.

\section{ARTICLE HISTORY}

Received:

01 Feb 2021

Revised:

15 Feb 2021

01 Apr 2021

10 Apr 2021

Accepted:

14 Apr 2021

\section{Introduction}

Education is essential for humans. Formal education starts in elementary school. In Indonesia, schools are divided into two, namely public schools and private schools. In this case, private elementary schools are more desirable than public schools. Private school graduates perform better (Bedi \& Garg, 2000). Apart from being taught general subjects, students who go to private schools are also taught religious education.

Besides, the label of a favorite school, especially Muhammadiyah elementary school, is not necessarily given to a school, but it goes through a long process. This label is given to schools that produce highachieving students, both academic and non-academic achievements, 
such as sports, music, arts, etc. Of course, this success is also influenced by the teachers who teach at the school. If the teacher's performance is good, it will have a positive effect on student achievement. Conversely, if the teacher's performance is not good enough, of course, it will harm student learning success. In fact, the teachers play a vital role because they deal directly with students. Good teachers can make a difference in their students' development (Fauth et al., 2019).

Based on previous studies, job performance was influenced by several individual antecedents, including organizational citizenship behavior (OCB). Performance was positively influenced by organizational citizenship behavior (Basu, Pradhan, \& Tewari, 2017; Kissi et al., 2019). Organizational citizenship behavior and job performance were also influenced by passion and empowerment.

Passion is a tendency or a strong desire for liked and considered necessary activities where a person is willing to invest his time and energy. According to Chummar, Singh, and Ezzedeen (2019), passion affected work-life, satisfaction, and performance, so it is crucial to consider individual and contextual conditions. As Dinnocenzo et al. (2016) revealed, there was a positive relationship between individual psychological empowerment and performance.

Therefore, this study discusses the role of organizational citizenship behavior in mediating the variables of passion and empowerment on performance. OCB serves as a mediating variable in this analysis, while in previous studies, these variables were not mediated by OCB.

\section{Literature Review and Hypotheses Development}

\section{The Effect of Passion on Organizational Citizenship Behavior}

Passion is described as an enthusiasm for a strong propensity to do things valued and valuable so that a person is prepared to spend his time and energy. Two kinds of passion exist, namely, harmonious and obsessive (Lafrenière, Vallerand, \& Sedikides, 2013). Obsessive passion refers to the impulses of desire that cause an individual to do certain things. Meanwhile, harmonious passion refers to the motivational force that directs an individual to participate in voluntary activities and produce the personal will and support to undertake these activities.

Meanwhile, organizational citizenship behavior is a voluntary human behavior whose discretion is acknowledged implicitly or expressly by the formal incentive structure of the organization (Hendrawan, Sucahyawati, \& Indriyani, 2017). Organizational citizenship behavior provides a way of managing interdependence between members of the work unit, according to Cheasakul and Varma (2016), which improves mutual outcomes and removes the need for organizations to allocate limited resources to basic care functions, freeing up resources to be more efficient and increasing capabilities. By taking time for more productive planning, scheduling, problem-solving, and so on, others do their works. 
Another view notes that $O C B$ is an additional initiative by employees not officially mandated by the company and a discretionary act by employees (Husniati \& Pangestuti, 2018).

In this regard, there is a substantial connection between the passion score for work and the behaviors score for organizational citizenship. Besides, there are substantial variations between workers with high and low corporate citizenship behavior and passion for work. High organizational citizenship activity is displayed by people who work with passion (Savithri \& Maharayazhmozhi, 2019).

\section{$\boldsymbol{H}_{1}$ : Passion has a positive and significant effect on organizational citizenship behavior}

\section{The Effect of Empowerment on Organizational Citizenship Behavior}

Empowering workers leads to higher job satisfaction, higher job productivity, increased engagement, higher morale, improved job quality, higher performance. Besides, it leads to teacher self-esteem, increased teacher awareness of subject matter and teaching methods, increased collegiality of employees, increased breakthroughs in curriculum initiatives, and increased student movement (Keiser \& Shen, 2000).

An essential positive relationship exists between the empowerment of workers and organizational citizenship behavior. It implies that if a person is in the highest role of empowerment, the organizational citizenship behavior will also be strong (Shahri et al., 2015). Moreover, employee empowerment is aligned with OCB's five dimensions: altruism (selflessness), sportsmanship, sensitivity (caution), civic virtue (social morality), and courtesy (politeness).

Workers agree that empowering employees can willingly increase their work, have fewer grievances, keep up to date with the latest details, and ensure equal pay equity. Employees believe that they can solve work-related issues by inspiring employees, retain a positive reputation by acquiring additional information to raise the status quo, and recognize coworkers in every sector (Noranee et al., 2018).

$\boldsymbol{H}_{2}$ : Empowerment has a positive and significant effect on organizational citizenship behavior

\section{The Effect of Organizational Citizenship Behavior on Job Performance}

Employee performance benefits from jobs in terms of quality and quantity, gained by workers under their duties (Lestari \& Ghaby, 2018). Employee performance can be viewed as a consequence of an employee's work in quality and quantity obtained in carrying out work under the responsibilities of the leadership. The performance itself is dependent on the standard or quality of work by employees (Nugroho \& Dewantara, 2016). 
The study results showed that OCB significantly predicted job efficiency. These results support statements from previous research, showing that through more effective planning, scheduling, and problem-solving, OCB could boost the capacity of colleagues and managers to do their jobs and contribute to service quality (Basu et al., 2017). According to Kissi et al. (2019), it can be inferred that OCB influenced success positively. Besides, employee efficiency may be influenced by the percentage of OCB reductions.

$H_{3}$ : Organizational citizenship behavior has a positive and significant effect on job performance

\section{The Effect of Passion on Job Performance}

Qadeer et al. (2016) found support for the concept that harmonious passion produces energy, creates engagement targets for workers, and impacts performance. An employee who is physically involved, emotionally driven, and cognitively channeled into work tasks leads to additional functional activities and improved job performance. According to Chummar et al. (2019), in work life, happiness and success, obsessive passion, and harmonious passion have the most significant impact, so it is essential to understand individual and contextual circumstances.

The greater the job passion of the employee, the higher the efficiency. Also, morale is a positive resource that can contribute to achievement in performance. To become their inner calling and purpose in life, individuals with high passion would love their works. Someone with a passion for work would also feel that work is a way of self-development that takes it to the whole of the workplace (Indriasari \& Setyorini, 2018). There is also a major opportunity for passion for work because it is connected to organizational success (Astakhova \& Porter, 2015).

$\boldsymbol{H}_{4}$ : Passion has a positive and significant effect on performance

\section{The Effect of Empowerment on Job Performance}

According to Dinnocenzo et al. (2016), the relationship between individual psychological empowerment and success is positive. However, for individuals employed in highly empowered units, but not for those working in units without empowerment, this relationship has been improved. The findings indicate that workers are constrained in conditions of low unit empowerment such that no empowerment results in low efficiency. Meanwhile, there is also an improvement in performance in a high unit empowerment state.

There is a substantial positive impact of both systemic and psychological empowerment on performance. Employee who feels motivated positively forecasts success structurally and mentally. Employees must be able to make decisions on their own. The more access to institutional empowerment they have, the higher their success is. Employees with high 
perceptions of psychological empowerment often deliver better performance (Arslan \& Zaman, 2014).

Employee empowerment in a company could have a positive impact on performance. The greater the employee empowerment's nature, the greater the company's efficiency is (Nadeem, Zia-ud-din, Riaz, \& Sattar, 2019).

$\boldsymbol{H}_{5}$ : Empowerment has a positive and significant effect on performance

\section{The Effect of Passion on Job Performance through Organizational Citizenship Behavior}

Passion for work positively influenced performance (Astakhova \& Porter, 2015; Chummar et al., 2019; Indriasari \& Setyorini, 2018; Qadeer et al., 2016). Passion is described as enthusiasm for a strong inclination towards valued and necessary activities so that someone is willing to spend his time and energy (Lafrenière et al., 2013). Meanwhile, employee performance benefits from jobs in terms of quality and quantity gained by workers under their duties (Lestari \& Ghaby, 2018).

Since workers enjoy what they do, high passion can make their efficiency higher. Besides, workers would be happy to spend their time and resources in their jobs to make success more rewarding than employees who are not excited about working.

Moreover, OCB applies to actions designed to assist coworkers, administrators, or organizations which involves assisting coworkers, attempting to raise morale, volunteering for positions that are not part of the job description, speaking favorably to outsiders regarding the company, and proposing changes. In this case, there is a vital connection between the passion for work and organizational citizenship behavior (Savithri \& Maharayazhmozhi, 2019). Similarly, there is a connection between organizational citizenship behavior and significant performance (Basu et al., 2017; Kissi et al., 2019).

$\boldsymbol{H}_{6}$ : Organizational citizenship behavior mediates the effect of passion on performance

\section{The Effect of Empowerment on Job Performance through Organizational Citizenship Behavior}

Passion for work positively influenced performance (Astakhova \& Porter, 2015; Chummar et al., 2019; Indriasari \& Setyorini, 2018; Qadeer et al., 2016). Passion is defined as enthusiasm for a strong tendency to liked and essential activities so that people are willing to invest their time and energy (Lafrenière et al., 2013). Meanwhile, employee performance results from work both in quality and quantity obtained by employees under their responsibilities (Lestari \& Ghaby, 2018). 
High passion will make employee performance better because employees like what they do. Besides, employees will be happy to invest their time and energy in their work so that performance will be more satisfying than employees who work not with passion.

Further, OCB refers to behavior intended to help coworkers, supervisors, or organizations and includes helping coworkers, trying to increase morale, volunteering for jobs that are not part of the job description, speaking positively about the organization to outsiders, and suggesting improvements in organizational functions (Husniati \& Pangestuti, 2018). There is a significant relationship between work passion and organizational citizenship behavior (Savithri \& Maharayazhmozhi, 2019). Likewise, there is relationship between organizational citizenship behavior and significant performance (Basu et al., 2017; Kissi et al., 2019).

$\mathrm{H}_{7}$ : Organizational citizenship behavior mediates the effect of empowerment on performance

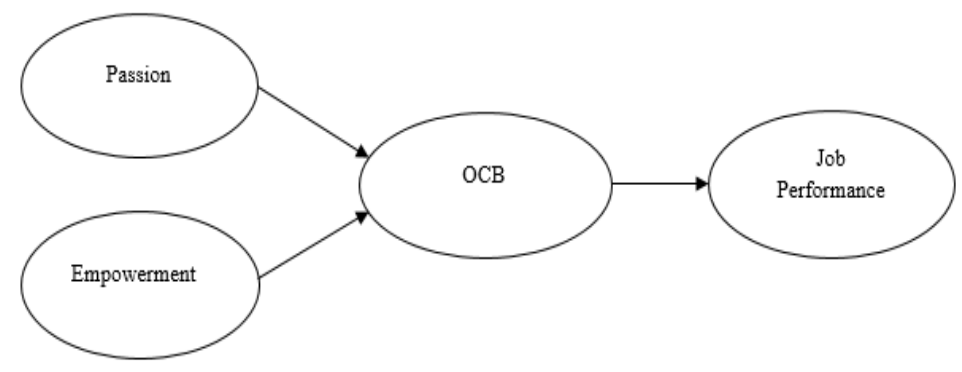

Figure 1 Research model

\section{Research Methods}

This study used a factor analysis method to answer the research objectives. This factor This quantitative research type used a survey. According to Sekaran and Bougie (2016), to define, compare, or illustrate individuals' awareness, attitudes, and behaviors, a survey is a system for gathering information from or about individuals (respondents). The relationship between variables of teacher passion, teacher empowerment, organizational citizenship behaviors, and teacher performance in Muhammadiyah elementary schools in Ngampilan and Wirobrajan Districts in the Yogyakarta region would be investigated in this research.

Teachers, according to Phelps and Benson (2012), have a significant impact in the classroom. If students have a loving teacher, they will be more motivated to learn more. It is where passion and empowerment come into play. Teachers who are passionate about their careers will understand that each class faces specific challenges. The more advanced the class, the more complex the challenges become. As a result, the principal must enable teachers to be flexible in their teaching and learning activities, as well as outside teaching and learning activities, including rest time, extracurricular activities, and congregational 
prayer. Teachers must also be active in voluntary activities outside of teaching and learning that can enhance their abilities and skills to improve their performance.

The population in this study were all Muhammadiyah elementary school teachers in Ngampilan and Wirobrajan Districts, Yogyakarta City. Based on the necessary education data of the Directorate General of Early Childhood Education, Primary, and Secondary Education, there were 10 Muhammadiyah elementary schools in Ngampilan and Wirobrajan Districts. The sample in this study was all teachers at Muhammadiyah elementary schools in Ngampilan and Wirobrajan Districts. The sampling technique used was nonprobability purposive judgment sampling, with the criteria of a minimum education of Bachelor Degree, teaching length over one year, and teaching at Muhammadiyah elementary schools in Ngampilan and Wirobrajan Districts. While the method employed was a survey. SEM-PLS's minimum sample size guide is ten times the maximum number of arrows (paths) hitting a latent variable in the PLS model. However, because this guide is still rough, it is advisable to use the Cohen approach, which considers the statistical power and effect size when determining the minimum sample size (Haryono, 2017). In this study, five arrows pointed to the latent variable so that the minimum sample size was 45 . The number of teachers who filled out the questionnaire was 57 , but only 51 questionnaires could be processed, as follows:

Table 1 Characteristic of Respondents

\begin{tabular}{llcc}
\hline & & Frequency & Amount (\%) \\
\hline Gender & Female & 39 & 76.47 \\
Recent education & Male & 12 & 23.53 \\
\multirow{3}{*}{ Working life } & Bachelor Degree & 49 & 96.08 \\
& Master Degree & 2 & 3.92 \\
& $1-5$ & 26 & 50.98 \\
& $6-10$ & 5 & 9.80 \\
& $11-20$ & 12 & 23.53 \\
& $>20$ & 8 & 15.69 \\
\hline
\end{tabular}

\section{Validity Test}

According to Sekaran and Bougie (2013), the validity test relates to whether the concept to be tested is correct or appropriate. If the test is said to be valid, then the researcher can proceed to the next stage. Based on the PLS model assessment criteria, the loading factor value so that the test is said to be valid is $>0.7$ or the t-statistic value 1.96 . The indicator is also said to be valid if the $P$ Value 0.05 . So that if all the indicators forming the construct are declared valid, they can be used to test hypotheses on structural measurements (Haryono, 2017).

\section{Reliablity Test}

The evaluation of the value of construct reliability is measured by the value of Cronbach's Alpha and Composite Reability. Cronbach's Alpha value for all constructs must be 0.7 . 
While the construct reliability value can be seen from the AVE value where the AVE limit value is 0.5 (Haryono, 2017).

\section{Variable measurement}

Passion

In this analysis, the researchers used a fourteen-item scale developed by Vallerand et al. (2003) to assess passion; (1) This work gives me the opportunity to obtain a wide range of perspectives; (2) The new thing I learned from my job makes it possible for me to earn more money; (3) This work presents me with life-changing experiences.

Empowerment of teachers

The calculation of teacher empowerment in this study was based on Dee et al.'s (2003) analysis, which included a total of twelve questions; (1) I had a significant influence on what occurred at school; (2). What happened at school was significantly influenced by me; (3) I have a large impact on what happens at school.

Organizational Citizenship Behavior

The scale utilized to assess organizational citizenship behavior comprised eight elements derived from Yilmaz and Taşdan's study (2009); (1) Outside of working hours, I assist students; (2) I spent the majority of my time in class; (3) I volunteer to assist other teachers.

Teacher Performance

The ten-item teacher performance assessment scale was derived from Davar \& Singh's (2018) study, which included ten questions; (1) I treat all of my students equally; (2) I demonstrate the skills, knowledge, and abilities needed to do my job effectively; (3) I finish my job on time and regularly.

\section{Results and Discussion}

\section{Construct Validity Measurement}

The sum of correlation between constructs and latent variables was determined by convergent validity. It could be seen from the loading factor value in determining convergent validity. The load factor value of 0.7 is optimal, implying that the indicator is true to calculate the structure it forms (Haryono, 2017). The model's modification was carried out three times by processing the data by stating a value less than 0.7 with the following results. 
Amalia, Wahyuningsih, \& Surwanti

The Mediating Role of Organizational Citizenship Behavior on the Effect of Passion ...

Table 2 Construct Validity Measurement

\begin{tabular}{|c|c|c|c|}
\hline Variable & Indicator & Loading Factor & Explanation \\
\hline \multirow[t]{8}{*}{ Job Performance } & KG01 & 0.735 & Valid \\
\hline & KG02 & 0.865 & Valid \\
\hline & KG03 & 0.815 & Valid \\
\hline & KG04 & 0.769 & Valid \\
\hline & KG05 & 0.755 & Valid \\
\hline & KG06 & 0.761 & Valid \\
\hline & KG07 & 0.838 & Valid \\
\hline & KG08 & 0.808 & Valid \\
\hline \multirow[t]{4}{*}{ OCB } & OC01 & 0.751 & Valid \\
\hline & OCO7 & 0.841 & Valid \\
\hline & OC08 & 0.804 & Valid \\
\hline & OC09 & 0.866 & Valid \\
\hline \multirow[t]{6}{*}{ Passion } & PA01 & 0.704 & Valid \\
\hline & PA03 & 0.757 & Valid \\
\hline & PA04 & 0.853 & Valid \\
\hline & PA05 & 0.720 & Valid \\
\hline & PA06 & 0.788 & Valid \\
\hline & PA07 & 0.780 & Valid \\
\hline \multirow[t]{5}{*}{ Empowerment } & PG07 & 0.819 & Valid \\
\hline & PG08 & 0.912 & Valid \\
\hline & PG09 & 0.857 & Valid \\
\hline & PG10 & 0.808 & Valid \\
\hline & PG12 & 0.820 & Valid \\
\hline
\end{tabular}

Based on the Table 2, several indicators were removed, including two indicators of teacher performance variables, eight indicators of organizational citizenship behavior variables, six indicators of passion, and seven indicators of teacher empowerment variables. After deleting the indicators, a research indicator with a value above $\geqslant 0.7$ was obtained, and it could be said to be ideal and valid in explaining the existing variables.

Reliability Construct Measurement

Table 3 Reliability Construct Measurement

\begin{tabular}{lcccc} 
& Cronbach's Alpha & rho_A & Composite Reliability & AVE \\
\hline Job Performance & 0.916 & 0.923 & 0.932 & 0.631 \\
OCB & 0.832 & 0.831 & 0.889 & 0.667 \\
Passion & 0.863 & 0.882 & 0.896 & 0.591 \\
Empowerment & 0.899 & 0.915 & 0.925 & 0.713 \\
\hline
\end{tabular}

Based on Table 3, it can be seen that the AVE value of each variable was $>0.5$, indicating a good measure of convergent validity. 
Inner Model Test

Table 4 Inner Model Test Result

\begin{tabular}{|c|c|c|c|c|c|}
\hline & $\begin{array}{l}\text { Original } \\
\text { Sample }\end{array}$ & $\begin{array}{c}\text { Sample } \\
\text { Mean }\end{array}$ & $\begin{array}{l}\text { Standard } \\
\text { Deviation }\end{array}$ & $\begin{array}{c}\mathrm{T} \\
\text { Statistic }\end{array}$ & $\begin{array}{c}\text { P } \\
\text { Values }\end{array}$ \\
\hline OCB -> Job Performance & 0.654 & 0.635 & 0.132 & 4.939 & 0.000 \\
\hline Passion -> Job & -0.096 & -0.084 & 0.124 & 0.778 & 0.437 \\
\hline \multicolumn{6}{|l|}{ Performance } \\
\hline Passion -> OCB & 0.597 & 0.609 & 0.153 & 3.901 & 0.000 \\
\hline $\begin{array}{l}\text { Empowerment -> Job } \\
\text { Performance }\end{array}$ & 0.354 & 0.363 & 0.14 & 2.520 & 0.012 \\
\hline Empowerment -> OCB & 0.057 & 0.075 & 0.245 & 0.234 & 0.815 \\
\hline
\end{tabular}

The next test was to test the feasibility of the model using the $\mathrm{R}$ square value with the following results:

Table 5 R Square

\begin{tabular}{ll}
\multicolumn{2}{l}{ R Square } \\
\hline Job Performance & 0.631 \\
OCB & 0.400 \\
\hline
\end{tabular}

The R square score for teacher performance was 0.631 , and the $R 2$ value for OCB was 0.4 . This figure shows that the variability of the endogenous variables explained by the passion and empowerment variables was $63.1 \%$ and $40 \%$, so other variables could still affect organizational citizenship behavior and teacher performance.

\section{Mediation Effect Test}

From the VAF (Variance Accounted For) value, the mediation effect could be seen. If the value of the VAF is above $80 \%$, then the function of the mediation barrier is complete mediation. In the meantime, it can be assumed that there is almost no mediation impact if the VAF value is between 20 percent - 80 percent, and it is in the category of partial mediation if the VAF value is less than 20 percent (Hermawan \& Hasibuan, 2016).

Table 6 Value of VAF

\begin{tabular}{|c|c|c|c|c|c|}
\hline & Direct & Indirect & Total & $\operatorname{VAF}(\%)$ & Explanation \\
\hline $\begin{array}{l}\text { Passion -> Job } \\
\text { Performance }\end{array}$ & 0.294 & 0.391 & 0.685 & 57.08 & Partial \\
\hline $\begin{array}{l}\text { Empowerment -> Job } \\
\text { Performance }\end{array}$ & 0.391 & 0.038 & 0.429 & 8.86 & Not mediated \\
\hline
\end{tabular}


The Mediating Role of Organizational Citizenship Behavior on the Effect of Passion ...

Hypothesis Test Results

Table 7 Hypothesis Test Results

\begin{tabular}{lccc}
\hline \multicolumn{1}{c}{ Variable } & T Statistic & VAF (\%) & Explanation \\
\hline Passion $->$ OCB & 3.901 & & H1 was accepted \\
\hline Empowerment $->$ OCB & 0.234 & H2 was rejected \\
OCB -> Job Performance & 4.939 & & H3 was accepted \\
Passion -> Job Performance & 0.778 & & H4 was rejected \\
Empowerment -> Job Performance & 2.52 & & H5 was accepted \\
Passion -> OCB -> Job Performance & & 57.08 & H6 was accepted \\
Empowerment $->$ OCB -> Job Performance & & 8.86 & H7 was rejected \\
\hline
\end{tabular}

\section{Discussion}

Hypothesis 1 testing findings indicate that passion had a strong positive influence on organizational citizenship behavior. The T statistical value was considered to be greater than 1.96, with an initial sample value of 0.597. This finding explains that Muhammadiyah elementary school teachers' passion in Ngampilan and Wirobrajan Districts affected the degree of organizational citizenship behavior. Teachers who are passionate about work will be mindful of the difficulties of teaching in their place, have a strong sense of identity, and believe in themselves that they will make a difference in the learning and success of all their students. Teachers are devoted to working collaboratively and cooperatively. Teaching is an innovative and daring career for them (Day, 2004). Organizational citizenship behavior refers to individual behavior to assist coworkers, raise passion, and volunteer for a job beyond the job description (Husniati \& Pangestuti, 2018). The teacher's interest in a role would provide the teacher with experience. Therefore, the more experience a teacher gets, the greater the employee's behavior to do work beyond the job description.

The findings of testing hypothesis 2 revealed that the variables of empowerment and organizational citizenship behavior had a positive and negligible impact. It was known from the value of the T figures, which was less than 1.96, and the value of the initial sample of 0.057 . This result explains that the empowerment of teachers did not impact organizational citizenship behavior at Muhammadiyah elementary schools in Ngampilan and Wirobrajan Districts. These findings support the findings of Bagheri, Zarei Matin, and Amighi (2011), who found no connection between empowerment and organizational citizenship activity. These results, however, contradict Kasekende et al. (2016), Shahri et al. (2015), and Noranee et al. (2018), who claimed that empowerment and organizational citizenship behaviors had a positive and vital relationship.

The findings of the hypothesis 3 test showed that OCB had a positive effect on teacher performance. The T Statistic value was greater than 1.96, and the original sample was positive. These results explain that the organizational citizenship behavior in schools influenced the performance of teachers. These findings are consistent with Basu et al.'s (2017) and Kissi et al.'s (2019) study, which found that positive organizational citizenship behavior impacted success. This finding, however, contradicts Hanafi, Bemby Soebyakto, 
and Afriyanti (2018) findings, claiming that organizational citizenship activity had no substantial impact on employee job performance.

Hypothesis 4 test results uncovered that the T Statistic value was 0.778 , and the original sample was negative. It means that passion did not affect teacher performance. The higher the teacher's passion, the lower the teacher's performance, and vice versa. This finding is not in line with the studies used as the source of this research, where previous research stated that the higher the passion, the higher the employee's performance. It can be explained by the fact that passion has five dimensions: a meaningful relation, internal drive, job immersion, joy, and energy (Monica \& Prasetya, 2015). Besides, the six metrics were omitted based on the data analysis that had been done, meaning that the data obtained had low normality. It could be affected by many factors, such as saturation, environmental conditions, or the present pandemic. It showed that hypothesis 4 was rejected.

The findings of the Hypothesis 5 test suggested that teacher empowerment and teacher success had a major positive impact. It could be seen from the T Static value of 2.520 and the original sample, which was positive, indicating that the greater the teacher's performance, the greater the empowerment of teachers at Muhammadiyah elementary schools in Ngampilan and Wirobrajan Districts. This result aligns with the research used in this study as a guide, which noted a positive relationship between empowerment and performance. This result is also consistent with the research used as a source of information for this report, which found a connection between empowerment and success. When it comes to improving teacher efficiency, schools offer teachers a lot of leeway. It is supported by a number of questionnaire claims, including mastery of skills, trust in their abilities, and work independently. It ensures that teachers are granted the opportunity to instruct or assist students in the manner that best suits their expertise.

The results of the hypothesis 6 test showed that passion had no direct influence on teacher performance but had a big impact on OCB, and OCB had a large impact on performance. These results suggested that the influence of passion on success was mediated by OCB. It could also be seen from the 57.08 percent VAF value, suggesting that the relationship between passion and teacher success was mediated by OCB. However, OCB was not the only variable affecting the relationship between passion and teachers' performance.

The last hypothesis test is hypothesis 7 , indicating that $O C B$ was not influenced by empowerment but affected teachers' performance explicitly. Similarly, OCB had a significant influence on teacher efficiency. Such results suggested that OCB did not mediate teacher success empowerment. Looking at the VAF value obtained of 8.86 percent, which was less than 20 percent, showed no mediation. 


\section{Conclusion}

Based on the research and testing that has been done, it could be concluded that: (1) Teacher passion had a positive and critical influence on organizational citizenship behavior. The greater the teacher's interest in doing a task, the greater the teacher's actions in working beyond the job description is; (2) The empowerment of teachers did not have an important and meaningful influence on organizational citizenship behavior. It implies that while teacher's empowerment and organizational citizenship behavior are strong, organizational citizenship behavior is not influenced by empowerment; (3) Organizational citizenship behavior had a positive and significant effect on teacher performance. The higher the teacher's behavior to work outside the job description, the higher the teacher's performance; (4) Passion for teachers did not have a major or detrimental impact on the performance of teachers. The lower the teacher's passion, the lower the commitment and performance the teachers will give; (5) Empowerment affected the performance of teachers positively and dramatically. It implies that the more flexibility teachers are provided in carrying out their work, the greater the success of their instructor; (6) The relationship between passion and teacher success was influenced by organizational citizenship behavior. It implies that if they pass organizational citizenship behaviors, the teachers' passion will boost performance; (7) The connection between empowerment and teacher performance was not mediated by organizational citizenship behavior. Empowerment had a positive and vital impact on teacher success without being mediated by organizational citizenship behavior.

\section{References}

Arslan, M., \& Zaman, R. (2014). Intellectual capital and its impact on financial performance: A study of oil and gas sector of Pakistan. International Letters of Social and Humanistic Sciences, 43, 125-140. https://doi.org/10.2139/ssrn.2520351

Astakhova, M. N., \& Porter, G. (2015). Understanding the work passion-performance relationship: The mediating role of organizational identification and moderating role of fit at work. Human Relations, 68(8), 1315-1346. https://doi.org/10.1177/0018726714555204

Bagheri, G., Zarei Matin, H., \& Amighi, F. (2011). The relationship between empowerment and organizational citizenship behavior of the pedagogical organization employees. Iranian Journal of Management Studies, 4(2), 53-62. Retrieved from https://iims.ut.ac.ir/article 23472.html

Basu, E., Pradhan, R. K., \& Tewari, H. R. (2017). Impact of organizational citizenship behavior on job performance in Indian healthcare industries: The mediating role of social capital. International Journal of Productivity and Performance Management, 66(6), 780 796. https://doi.org/10.1108/IJPPM-02-2016-0048

Bedi, A. S., \& Garg, A. (2000). The effectiveness of private versus public schools: the case of Indonesia. Journal of Development Economics, 61(2), 463-494. https://doi.org/10.1016/S0304-3878(00)00065-1

Cheasakul, U., \& Varma, P. (2016). The influence of passion and empowerment on organizational citizenship behavior of teachers mediated by organizational commitment. Contaduria y Administracion, 61(3), 422-440. https://doi.org/10.1016/j.cya.2016.04.003 
Chummar, S., Singh, P., \& Ezzedeen, S. R. (2019). Exploring the differential impact of work passion on life satisfaction and job performance via the work-family interface. Personnel Review, 48(5), 1100-1119. https://doi.org/10.1108/PR-02-2017-0033

Day, C. (2004). A passion for teaching. London: Routledge. https://doi.org/10.4324/9780203464342

Dinnocenzo, L., Luciano, M. M., Mathieu, J. E., Travis Maynard, M., \& Chen, G. (2016). Empowered to perform: A multilevel investigation of the influence of empowerment on performance in hospital units. Academy of Management Journal, 59(4), 1290-1307. https://doi.org/10.5465/amj.2013.1073

Fauth, B., Decristan, J., Decker, A. T., Büttner, G., Hardy, I., Klieme, E., \& Kunter, M. (2019). The effects of teacher competence on student outcomes in elementary science education: The mediating role of teaching quality. Teaching and Teacher Education, 86, 102882. https://doi.org/10.1016/i.tate.2019.102882

Hanafi, A., Bemby Soebyakto, B., \& Afriyanti, M. (2018). The effect of Organizational Citizenship Behavior (OCB) and Quality of Work Life (QWL) on the employee work performance with motivation as an intervening variables at industrial affairs of South Sumatera province. International Journal of Scientific Research and Management, 6(09), 676685. https://doi.org/10.18535/ijsrm/v6i9.em03

Haryono, S. (2017). Metode SEM Untuk Penelitian Manajemen dengan AMOS LISREL PLS. Jakarta: Luxima Metro Media.

Hendrawan, A., Sucahyawati, H., \& Indriyani, I. (2017). Organizational Citizenship Behavior (OCB) pada karyawan akademi maritim nusantara. Prosiding Seminar Nasional \& Internasional, Universitas Muhammadiyah Semarang. Retrieved from https://jurnal.unimus.ac.id/index.php/psn12012010/article/view/2271

Hermawan, R., \& Hasibuan, S. (2017). Analisis pengaruh tingkat pengalaman dan coaching style terhadap kualitas kepemimpinan manajer proyek dalam upaya peningkatan produktivitas di PT. JCI. Jurnal PASTI, 11(1), 84-97. Retrieved from https://publikasi.mercubuana.ac.id/index.php/pasti/article/view/1357

Husniati, R., \& Pangestuti, D. C. (2018). Organizational Citizenship Behavior (OCB) pada pegawai UPN “Veteran” Jakarta. Jurnal Bakti Masyarakat Indonesia, 1(1), 234-241. Retrieved from https://journal.untar.ac.id/index.php/baktimas/article/view/1902

Indriasari, I., \& Setyorini, N. (2018). The impact of work passion on work performance: the moderating role of P-O fit and meaningfulness of work. Diponegoro International Journal of Business, 1(1), 26. https://doi.org/10.14710/dijb.1.1.2018.26-32

Kasekende, F., Munene, J. C., Otengei, S. O., \& Ntayi, J. M. (2016). Linking teacher competences to organizational citizenship behaviour: The role of empowerment. International Journal of Educational Management, 30(2), 252-270. https://doi.org/10.1108/IJEM-10-2014-0140

Keiser, N. M., \& Shen, J. (2000). Principals' and teachers' perceptions of teacher empowerment. Journal of Leadership Studies, 7(3), 115-121. https://doi.org/10.1177/107179190000700308

Kissi, E., Asare, O. A., Agyekum, K., Yamoah Agyemang, D., \& Labaran, M. (2019). Ascertaining the interaction effects among organisational citizenship behaviour, work overload and employees' performance in the Ghanaian construction industry. International Journal of Productivity and Performance Management, 68(7), 1235-1249. https://doi.org/10.1108/IJPPM-07-2018-0262

Lafrenière, M. A. K., Vallerand, R. J., \& Sedikides, C. (2013). On the relation between selfenhancement and life satisfaction: The moderating role of passion. Self and Identity, 12(6), 597-609. https://doi.org/10.1080/15298868.2012.713558

Lestari, E. R., \& Ghaby, N. K. F. (2018). The influence of Organizational Citizenship 
Amalia, Wahyuningsih, \& Surwanti

The Mediating Role of Organizational Citizenship Behavior on the Effect of Passion ...

Behavior (OCB) on employee's job satisfaction and performance. Industria: Jurnal Teknologi dan Manajemen Agroindustri, 7(2), 116-123.

https://doi.org/10.21776/ub.industria.2018.007.02.6

Monica, M., \& Prasetya, W. (2015). Terhadap motivasi kerja dan potensi individu (Studi kasus: Pada PT. Asjaya Indosurya Securities). Seminar Nasional Sains dan Teknologi Universitas Mubammadiyah Jakarta.

Nadeem, M. T., Zia-ud-din, M., Riaz, W., \& Sattar, A. (2019). The effects of employees empowerment on organizational performance : A case of hotel industry in Pakistan. International Journal of African and Asian Studies, 47, 89-94. Retrieved from https://www.iiste.org/Journals/index.php/JAAS/article/view/43317

Noranee, S., Abdullah, N., Mohd, R., Khamis, M. R., Aziz, R. A., Som, R. M., \& Ammirul, E. A. M. (2018). The influence of employee empowerment on organizational citizenship behavior. Proceedings of the 2 nd Advances in Business Research International Conference, 305-313. https://doi.org/10.1007/978-981-10-6053-3 29

Nugroho, P., \& Dewantara, R. (2016). Analisis pengaruh kemanfaatan penggunaan sistem on-line passion terhadap kinerja karyawan (Studi pada PT Pegadaian (Persero) Kantor Cabang Blimbing Malang Periode 2015). Jurnal Administrasi Bisnis Universitas Brawijaya, 38(2), 163-171. Retrieved from http://administrasibisnis.studentjournal.ub.ac.id/index.php/jab/article/view/1522

Phelps, P. H., \& Benson, T. R. (2012). Teachers with a passion for the profession. Action in Teacher Education, 34(1), 65-76. https://doi.org/10.1080/01626620.2012.642289

Qadeer, F., Ahmad, A., Hameed, I., \& Mahmood, S. (2016). Linking passion to organizational citizenship behavior and employee performance: The mediating role of work engagement. Pakistan Journal of Commerce and Social Sciences (PJCSS), 10(2), 316-334. Retrieved from https:// papers.ssrn.com/sol3/papers.cfm?abstract id $=2832180$

Savithri, J. J., \& Maharayazhmozhi, M. S. (2019). Effect of work passion on organizational citizenship behaviour. International Journal of Business and Management Invention, 8(1), 6-10. Retrieved from http://www.ijbmi.org/v8i1(series3).html

Sekaran, U., \& Bougie, R. (2016). Research method for business. United Kingdom: John Wiley \& Sons, Inc.

Shahri, M.H.M., Abdi, S., Yazdankhah, M., \& Heydari, F. (2015). The relationship between empowerment and organizational citizenship behavior of staff in youth and sports general office of Khorasan Razavi. International Journal of Sport Studies, 5(4), 475-481. 